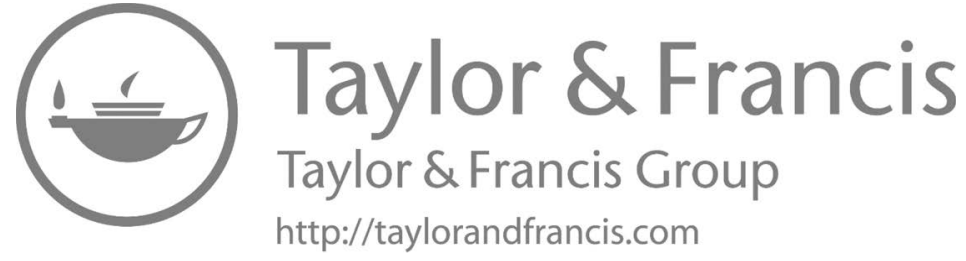




\title{
13
}

\section{BRAZIL AND THE FIGHT AGAINST COVID-19}

\section{Strengthening state and municipal powers}

\author{
Gilberto M. A. Rodrigues, Vanessa Elias de Oliveira, \\ Marcelo Labanca Corrêa de Araújo and Sérgio Ferrari
}

\subsection{Introduction}

From the outset of the Covid-19 pandemic, a central feature of federalism in Brazil was the strong role played by state governors and the fact that this stood in contrast to the denialism of the President Jair Bolsonaro, who neglected his federal responsibilities. Whereas the President refused to support isolation measures and import medicines and supplies for curbing the pandemic, governors quickly performed these tasks. Subnational responsibility was confirmed by the Supreme Court, giving governors and mayors important political visibility and shaking up the entrenched structures of Brazil's centralised federalism.

This chapter discusses the dual nature of Brazilian federalism, as evidenced by the Covid-19 pandemic. On the one hand, the crisis highlighted the importance of the federal government in the institutional arrangement of Brazilian federalism, which is highly centralised; on the other hand, it has provided greater scope for action by state governments, whose political power has gradually diminished over the 30 years since the 1988 Constitution came into being.

The Federative Republic of Brazil is the largest country in South America and the fifth largest in the world. Its Constitution of 1988 makes it a significantly decentralised federation in terms of the distribution of political power and fiscal resources between the three levels of government - federal, state, and municipal - each of which consists of 'federative entities' (Souza 1997). Brazil is also highly socio-economically heterogeneous, a fact that presented considerable challenges in its efforts to confront the Covid-19 pandemic.

Politically, too, the country is fragmented, with 24 political parties represented in Congress, the federal parliament. The 10 with the largest congressional representation are the Brazilian Democratic Movement (MDB), Workers' 
Party (PT), Brazilian Social Democratic Party (PSDB), Progressive Party (PP), Democratic Workers' Party (PDT), Brazilian Workers' Party (PTB), Democrats Party (DEM), Liberal Party (PL), Brazilian Socialist Party (PSB), and Republicans. However, governability in Congress depends as well on small parties without an ideological affiliation; in addition, a strong conservative multiparty caucus - the so-called beef, bullets, and bible lobby - supports the government in pursuit of specific interests, with the focus falling variously on agrarian matters ('beef'), law and order ('bullets'), and religion ('bible').

President Bolsonaro was elected by a small party, the Liberal Social Party (PSL), which espouses anti-political-system rhetoric. He left it in November 2019 but was unable to create a new one and thus remained without party affiliation during the 2020 pandemic. In the absence of a formal coalition, Bolsonaro relied on unstable support from conservative parties in Congress. In regard to state-level opposition politics, opposition governors are from a broad ideological spectrum ranging from the political left to the right.

The Brazilian population is relatively young: in 2019, 42.3 per cent of people in a population of about 210 million were less than 30 years of age (IBGE 2019a). Approximately 85 per cent of the population live in cities, but regional disparities are large: city dwellers make up 93 per cent of the population in the Southeast region of the country, but the proportion drops to 73 per cent in the Northeast. Although cities have a higher population density than peri-urban and rural areas and were disproportionately affected by the pandemic, health services are also concentrated in these areas, thanks to which treatment was readily accessible there.

Brazil has a mixed public and private health-care system, with the vast majority (75 per cent) of the population using the public National Health System (SUS) and only 25 per cent having private health insurance (Scheffer et al. 2015). Spending per capita is USD 1,282 when the public and private sectors are combined; however, it is much lower than this if one considers the public health service alone, which covers most of the population. Public health spending in this respect is USD 551 per capita per year (43 per cent of total spending in 2017, according to the Organisation for Economic Co-operation and Development (OECD 2019)). According to the World Bank, public spending on health in 2018 accounted for 3.9 per cent of gross domestic product (GDP) - this is lower than the average for Latin America and the Caribbean as a whole (4.1 per cent), and the average of 6.5 per cent presented by the OECD countries (OECD 2019).

It was in the big cities, especially São Paulo and Rio de Janeiro, that Brazil recorded its initial cases of Covid-19; the first to come to light was on 25 February 2020 and concerned a traveller returning from Italy (Department of Health 2020). Several days after a pandemic was declared by the World Health Organization (WHO) on 11 March, the states of São Paulo and Rio de Janeiro were the first in Brazil to introduce quarantine measures. On 20 March, the country's Ministry of Health confirmed the domestic spread of the virus. 
Given that the federal government opposed isolation and quarantine, a policy of social distancing was not introduced uniformly across the country; even so, 15 of Brazil's 26 states, along with the Federal District, adopted these measures. The latter were important in reducing the initial transmissibility rate (i.e. the number of persons infected by one infected person), which was estimated at three - much higher than the average at the height of the pandemic in Europe, where the mean rate was 1.6. By 31 October 2020, Brazil had the third highest number of cases (about 5 million) and second highest number of deaths (more than 160,000) in the world, in this regard trailing behind only the United States. More than a third of the cases were concentrated in the Southeast region (Candido et al. 2020). On 14 November, the transmissibility rate had decreased to 0.94 (Imperial College 2020).

However, a series of problems indicated that the situation was more serious than the data suggested. Firstly, Brazil's rate of Covid-19 testing was very low; secondly, there would be a delay between the occurrence of a case and/or death and the official report of it; and, thirdly, in the middle of 2020, the Brazilian Ministry of Health changed the system for counting cases.

\subsection{The federal constitutional and legislative framework}

Brazil has a federal constitution that establishes three levels of government: the federation, the states, and the municipalities, each of which has its own administrative and legislative powers. States and municipalities enjoy political and constitutional autonomy (Ferrari 2015; Rodrigues 2018) whereby governments are chosen without the interference of the federal authorities, and legislative and administrative powers are held without the need to submit to any consultation, approval, or referendum at the federal level. Law-makers in the three spheres are elected in their respective constituencies, and, likewise, there is no interference on the part of any federal organ.

The division of powers adopted by the 1988 Constitution combines dual and cooperative models of federalism. Specific powers are reserved for the union (the federal government), with a residual clause pertaining to state governments (Constitution, article 25). This model is based on the United States' division of powers into those enumerated for the federal government and those reserved to the states, as provided for in the 10th Amendment. However, powers in a cooperative federation may also be shared or concurrent. In reference to the concurrent powers of cooperative federalism, the 1988 Constitution uses the expression 'in common' in article 23 to assign the administrative powers of entities, and the term 'concurrently' in article 24 to refer to legislative powers. The terms 'common' and 'concurrent' thus refer, in the system of shared powers of the 1988 Constitution, to the fields within which federal, state and municipal governments operate jointly in administrative or legislative matters (Rodrigues 2017).

Two features of Brazilian federalism tend to confer heightened status to cities. In the first, the political autonomy of municipalities is guaranteed in the 
Constitution; in the second, municipalities are given extensive responsibility for social and urban policies. In regard to health care, they are responsible for the provision and management of primary health care ('basic care units') through municipal structures co-funded by the federal government. Municipalities are also responsible for urban transport, except for metropolitan bus services, while subways and urban railways are managed by the states. They (municipalities) are responsible too for establishing and running municipal schools for children between the ages of 6 and 15 years. In all such activities, mayors and city councils enjoy full jurisdiction.

One recurrent criticism of Brazilian federalism concerns the concentration of powers vested in the central government. Article 21 lays out 25 administrative matters over which the union has exclusive power, while article 22 lays out 29 further issues covered solely by laws of the union. The field of health is shared and, according to article 23, the promotion and protection of health is a concurrent power. The union has the power to draw up general legal frameworks in this field, leaving states and municipalities free to draft specific legislation. The actual provision of health services is the responsibility of all levels and should be accomplished in a decentralised manner (Constitution, articles 196 and 198(I)). Health legislation relating to Covid-19 passed by the National Congress thus fits into the category of a framework law, forming a kind of legislative condominium with state and municipal legislation.

With regard to disaster management-related legislation, four concepts in Brazilian law are to be distinguished from each other: a state of emergency, a state of disaster, a state of national defence, and a state of siege. The last two are provided for in the Constitution but have never been invoked (being for use when public order and the peace are threatened by extreme institutional instability, or in the case of war). Thus, in the Covid-19 crisis, Brazil declared, first, only a state of emergency and, then, a state of disaster. These two institutions are provided for by infra-constitutional frameworks without a specific constitutional foundation.

A state of emergency occurs when there are grounds to fear that the operation of the health system by public authorities may be overwhelmed and public safety jeopardised. It is declared to prevent harm. At the federal level, this issue is governed by Decree No. 7616 of 2011, which establishes the procedures to be followed when declaring a state of 'national health emergency' (ESPIN) in the case of epidemics, disasters, or lack of assistance to the population. Once an ESPIN has been declared, it is possible to adopt exceptional measures, such as the requisition of goods and services and the contracting of temporary staff. The federal government is required to act in conjunction with affected states and municipalities.

By contrast, a state of disaster occurs when the actions of public authorities and the health of the population have been compromised already in actuality (as opposed to when - as in a state of emergency - it is feared that this could happen). In case of disaster management, the federal government should play a 
coordinating role in which it works in concert with state and municipal plans to counter the effects of the disaster.

The Federal government has a National System of Security and Civil Defence (SINPEC) in which federal, state, and municipal authorities participate. Law 10954 of 2004 provides for emergency assistance to be given to the affected population, while Law 12340 of 2010 governs the transfer of funds from the union to state and municipal governments to support the emergency response and recovery of affected areas.

States and municipalities are not involved in the drafting of federal legislation other than, in the case of states, indirectly through the Federal Senate (which, in terms of article 48 of the Constitution, represents their interests); instead they implement and enforce national legislation, within the concurrent powers arrangement. Through their legislation, states and municipalities may also declare states of emergency or disaster (but not of defence or siege).

In principle, the federal government does not have the prevalence to declare a state of emergency and a state of disaster, since states and municipalities have equal powers to declare states of emergency or disaster within their respective remits. However, for states and municipalities to acquire funds from the federal government, they must submit to the legal criteria established by the federal legal framework.

Accordingly, Law 12608 of 2012 outlines national security and civil defence policy and stipulates the powers reserved to the union, in particular that of 'establishing the criteria and conditions for the declaration and recognition of situations of emergency and a state of public disaster' (article 6(10)). Thus, despite the autonomy of the states and municipalities in authorising the declaration of a state of emergency or disaster, its recognition by the federal government may operate as a form of control. Law 12608 contains a section that defines the powers of each unit of the federation - the union (article 6), the states (article 7), the municipalities (article 8) - and, finally, all three (article 9).

The situation in Brazil during the 2020 pandemic was unparalleled in recent history. States of emergency and disaster had been declared before, especially in the event of natural disasters, but not on the same scale as in the response to Covid-19. In such events, the federal government produces central records recognising states of emergency and disaster (many of which relate to droughts, floods, and landslides) and monitors the situation by means of an integrated disaster information management system indicating the locations on the map where the crisis is in force.

\subsection{Preparedness for a national disaster: The institutional framework}

Despite the existence of the SINPEDC national security and civil defence system, Brazil has no agency specifically responsible for responding to disasters. Disaster management is provided as the situation demands and organised in a decentralised way. Civil defence is coordinated at the state and municipal levels. 
The organisation best equipped to deal with disasters is the Fire Service, which is a state-level entity organised as a military fire service. In cases of accidents or environmental disasters, such as the bursting of dams built by mining companies, the civil defence force and the Fire Service (both of which are state organisations) work together with the civil defence forces of the municipalities concerned. In such cases, federal agencies conduct investigations, initiate administrative procedures, and impose administrative fines and punishments. In extreme cases, the (federal) armed forces may be used, but this must be at the request of the governors.

In regard to public health, the prevention and management of disasters depend on agencies and organisational systems specific to this field. Under normal political circumstances, public health crises of national proportions are addressed primarily by the Ministry of Health and the National Health Council.

The federal government has at its disposal an autonomous agency - the Brazilian National Health Regulator (ANVISA) - which has administrative policing power to intervene in the national territory in cases of epidemics and pandemics. Its scope of action is broad and affects various aspects of public health. Under normal circumstances, it provides health surveillance in border regions, ports, and airports; approves medication for use; and oversees health conditions at industrial, commercial, and service establishments in cities and rural areas. ANVISA is an agency that enjoys widespread public confidence. At the federal level, it has a well-trained professional technical staff that follows the recommendations of the WHO and the Pan-American Health Organisation.

The Brazilian National Health System (SUS) has a federated structure and depends on cooperation between the three levels of government. It has some institutional instruments for coordination, such as the Two-Party InterAdministration Commission (which brings together municipal and state managers) and the Three-Party Inter-Administration Commission (involving all three levels of government). These management structures promote dialogue between governments within each state and in the federation as a whole.

A number of previous health crises, such as the Zika and H1N1 virus epidemics, have posed a significant challenge to the Brazilian public health system, but nothing has been comparable to the challenges posed by Covid-19. For example, the low rate of testing by the three levels of government adversely affected Brazil's efforts in dealing with the pandemic (Magno et al. 2020). Eight months after the first case in Brazil, the federal and state governments were still unable to solve the problem of insufficient testing, as a result of which the number of infected individuals continued to be underestimated. In April 2020, the number of tests per thousand inhabitants in Brazil was 0.63, which was far lower than the rate in other Latin American countries (Our World in Data 2020). The only persons who were tested were frontline health workers, those who had been hospitalised, and, in some states, those suspected of having died as a result of Covid-19. Consequently, as França et al. (2020: 1) noted, 'the two major challenges are that 
of estimating the scale of underreporting Covid-19 deaths and that of determining what the exact figure should be'.

In addition, richer states conducted more testing than poorer ones, both because these states could afford to do so and because of the huge presence within them of the private health system. Richer states also paid for patients' tests.

\subsection{Rolling out measures to contain the pandemic}

Since President Bolsonaro took office, the political situation in Brazil has been anomalous due to his ideologically polarising rhetoric and adoption of an agenda that denies science. Under the circumstances, the federal executive did not, as it should have, respond effectively to the outbreak of the pandemic by heeding practical administrative and technical expertise in this field. There was, from the outset, thus no coherent political approach to the pandemic, which worsened as time went on. The fact that opposition parties governed the major states and cities exacerbated the lack of unity of purpose.

One of the tragic aspects of federal mismanagement of the pandemic was the negligence shown towards indigenous populations. Brazil has a diversity of indigenous ethnic groups, who inhabit territories that are scattered across the country and which comprise 13 per cent of the national territory (Castro and Rodrigues 2010). The indigenous population is estimated to number 1 million people (IBGE 2019b). Although their immunological status puts them at a high risk of infection and fatality, the federal government refused to adopt protective measures suited to their needs. The Covid-19 pandemic worsened the plight of indigenous peoples, who were already burdened by the Bolsonaro government's regressive environmental and human rights policies. They have been threatened with forced assimilation, the suspension and revision of their land rights, and the re-demarcation of their territories. Allegations of genocide against indigenous peoples by President Bolsonaro were referred not only to the United Nations Human Rights Council but the International Criminal Court (ICC), whose Rome Statute Brazil has ratified and whose decisions it is thus legally bound to accept (Connectas Human Rights 2020).

In reaction to the President's Covid-19 denialism, the Federal Supreme Court supported states and municipalities, thereby strengthening their role in the federation during the pandemic. It held in particular that the federal government was neglecting its coordinating role and, worse yet, flouting the recommendations of the WHO. The Court maintained that this jeopardised the security of the Brazilian population and necessitated decentralised government action in line with the recommendations. The ruling would appear to reflect a political position on the value of health and human life rather than a change in the Court's interpretation of the Brazilian federal system (Araújo and Liziero 2020). 


\subsubsection{Taking the initiative}

The first political reactions, both from the President and the governors, revealed the leaders' differences in viewpoint on the pandemic. While President Bolsonaro minimised it, describing Covid-19 as a 'small flu', governors quickly sought to tackle it by setting up teams of political leaders and medical experts. Despite the President's stance, the federal health minister acted promptly; their divergent perspectives on viral transmission led to conflict, however, and culminated in the health minister's resignation a month after the health crisis began.

On 3 February 2020, the Brazilian Ministry of Health published Ordinance No. 188, marking the start of the state of emergency relating to Covid-19. Law No. 13979 of 6 February 2020 likewise established the basis for adopting a series of measures for confronting the Covid-19 emergency, such as isolation and quarantine, compulsory medical examinations, and restriction of movement within and into the country. Moreover, a state of disaster was declared in Brazil by Legislative Decree No. 6 of 20 March 2020.

Directly after the first federal initiatives, state governors began to react. The Federal District of Brasilia was the first subnational entity to adopt restrictive measures, doing so on 11 March when it suspended classes in all educational institutions. In the most populous state in the country, São Paulo, restrictive measures were taken on 13 March with the suspension of commemorative events. Then, still in March, all shops, restaurants, and schools were closed. Other states followed suit and took similar measures, such as Rio de Janeiro on 19 March. The states adopted measures based on their monitoring of infection rates and the occupancy rates of hospital beds (Agência Brasil 2020).

A key feature of Brazil's management of the pandemic was the conflict between the federal and subnational governments regarding social isolation. As noted, President Bolsonaro reacted to the first cases of Covid-19 by denying the gravity of the situation and the need for social isolation. Despite clear scientific proof of the importance of isolation in containing transmission, the President continued to argue that the policy of social isolation adopted by state and municipal governments was damaging to the economy and should therefore be discontinued.

Under such circumstances of inaction and misrepresentation by the federal government, various state governors used the power they share with the union in managing public health crises to introduce measures, rejected by the President, regarding social isolation and the obligatory use of masks in public places. The suspension of operations at schools, businesses, services, and locations open to the public was decreed by state governments as an emergency measure to contain the pandemic.

The President made several verbal attacks on isolation measures and governors and mayors who adopted them - through social media, he continued all the while to incite his supporters to flout these measures. For their part, states began to implement various public health measures. State opposition to the federal 
government on these issues had no direct relationship to party politics; indeed, at the time, the President had no party. The opposition by states was instead due to his denialist attitude towards science.

\subsubsection{Federal action}

Numerous federal laws were enacted in response to Covid-19. Among others, Provisional Measure 927 of 22 March 2020 concerns labour law during the pandemic; Law No. 14010 of 10 June 2020 established an emergency legal framework for legal relations in private law; and Law No. 14021 of 7 July 2020 set out measures to protect indigenous and quilombola (African-Brazilian) communities from the pandemic. The measures were intended to protect jobs and also to adapt contracts signed between private actors in a way to fit them into the new panorama of the pandemic. In relation to indigenous peoples and quilombolas, the measures were intended to protect them and their cultural heritage through the provision of an emergency plan that included quick tests and construction of field hospitals near their villages. Various laws were also passed to mitigate the economic consequences of the pandemic and assist the most vulnerable sectors of the population. The congressional legislature was not suspended during the pandemic but continued operations by way of virtual sessions.

This legislative industriousness gives little indication, though, of the tensions that underlay the federal government's pandemic response, in particular the controversies surrounding its Ministry of Health. Brazil had three health ministers during the 2020 pandemic. After clashing with the initial Minister of Health, Luiz Henrique Mandetta - events that culminated in the latter's resignation on 16 April 2020 - the President appointed the renowned doctor, Nelson Teich, in Mandetta's stead; he, however, did not accept the President's anti-scientific stance, either, and spent only a month in office. Thereafter the President decided to militarise the Ministry. Eduardo Pazzuelo, a general specialising in logistics and with no prior experience in public health, was made Minister of Health in September 2020 after having held the position on an interim basis for around four months.

Arguably, President Bolsonaro impaired a crucial office and misused resources of specialist expertise that could have helped the executive branch manage the pandemic at federal level. As mentioned, he underplayed the risk of contagion and its grave consequences for the health of the population, and questioned the WHO's recommendations regarding the use of masks and social isolation. He also urged the population to remain at work and lead normal lives, thereby giving priority to the economy to the detriment of public health. The resignation of two health ministers sent a clear message that the President had decided not to accept WHO protocols; instead he elected to adopt obscure, non-transparent criteria to manage the pandemic, to publish incomplete accounts of case numbers and fatalities, and to support Covid-19 treatments not endorsed by the WHO, such as hydroxychloroquine. 
Given the President's stance, Brazil was soon to face a conflict over jurisdiction in emergency measures. Law No. 13979 of 6 February 2020 drew up a list of drastic measures that could be adopted, including isolation, quarantining, restriction of activities, compulsory medical examinations, restrictions on entering and leaving the country, and requisitioning goods and services. Although subnational administrations are empowered to take measures to counter pandemics, Provisional Measure 926 of 20 March amended the federal legal framework to determine that the President would have the competence to list the essential services that could not stop, as well as to establish the need for previous authorisation from the regulatory agencies so that the restriction measures could be adopted by governors and mayors.

This requirement was challenged before the Supreme Court, which in two decisions came down firmly in favour of the states. In the first case (Unconstitutionality Direct Action 6341/DF), the Democratic Workers' Party sought to ensure that the measures provided for in the federal law would not exclude the possibility of state action and would not depend on authorisation from the federal government. The Court decided on 15 April, confirming an earlier injunction of $24 \mathrm{March}$, that the possible measures adopted by the federal government did not exclude the possibility of normative and administrative measures by the states, the federal district, and municipalities.

In the second case (Non-compliance of Basic Principles 672/DF), the Brazilian Bar Association asked the Court, on April 1st, to order the President to abstain from committing acts contrary to the social isolation policies adopted by the states and municipalities. The Court responded quickly, on April 9th, reinforcing subnational governments for issuing decrees, free of federal government supervision, legally provisioned restrictive measures, such as social distancing and isolation, suspension of activities at schools and universities, and restrictions on commercial and cultural activities and the free movement of people.

The Court thus adopted a position affirming decentralisation and recognising the action of states and municipalities in introducing measures to control the pandemic. Justice Ricardo Lewandowski expressly said in a conference at an academic congress (organised by the Brazilian Bar Association) that the Federal Supreme Court had reassessed federalism during the pandemic and that the ruling did not reflect the Court's traditional position (Notícias STF, 2020). Indeed, the literature shows that Brazilian federalism is usually centralised and that the Supreme Federal Court has tended either to reinforce this (Lorencini et al. 2017) or to ignore the debate on federal powers, with the Court in various cases having sided with the federal government and overruled state governments (Araújo 2009).

Apart from the dispute between federal entities about social isolation, another controversial measure by the federal government was its promotion of hydroxychloroquine as an effective treatment for Covid-19. The day after Eduardo Pazuello took office as interim Minister of Health, he signed an ordinance authorising the use of this medication in the public and private health-care 
system, doing so without prior authorisation by the country's health regulator, ANVISA, which is responsible for approving medications for clinical use. As an emergency measure, the Brazilian Army Pharmaceutical Laboratory (LQFEx) then started to produce hydroxychloroquine, for which it had acquired BRL 1.5 million worth of hydroxychloroquine powder without putting the acquisition out to competitive tender. In June 2020, the Federal Court of Accounts (TCU 2020) launched an investigation into the purchase, which was suspected to have involved overbilling.

The medication thus produced, amounting to three million pills, did not go unused, though. The President's vocal support of it led to a frenzied rush to acquire it, especially by the mayors of rural towns, who, as part of their campaigns for re-election in November 2020, distributed it as a way of associating themselves with the President and demonstrating they were in control of the disease. By mid-August, Minister Pazzuelo announced that there was a shortage of hydroxychloroquine; however, the army had not resumed production (CNN Brasil 2020).

Despite the federal government's disastrous performance, autonomous federal institutions made significant contributions to the effective management of the pandemic. Public federal universities (of which there are 68 in the country) undertook important studies on diagnostic tests, vaccines, and improved treatment of Covid-19. Another key federal institution is the Oswaldo Cruz Foundation, which conducted diagnostic tests and research (Fiocruz 2020).

\subsubsection{State action}

State governments played an outstanding role in curbing the pandemic. They did so primarily by responding promptly to the first cases of Covid-19 and adopting quarantine and other social isolation measures, such as the closure of schools and public parks and suspension of non-essential commerce and services. Moreover, the failure of the federal government to provide technical and financial assistance to the states, which are responsible for a large number of public hospitals, prompted some governors to pursue alternative routes, such as importing medical equipment (masks, tests, ventilators, and the like) directly from foreign countries without the intervention of the federal government. São Paulo, Rio de Janeiro, and Maranhão (all governed by President Bolsonaro's opponents) were among the states to take steps of this kind.

In particular, the need to purchase large numbers of ventilators and expand intensive care units (ICUs) posed a significant challenge to the health-care system in Brazil. The federal response in this regard was slow, resulting in shortages of beds and equipment. Several states hired private facilities to enable the public health system to meet demand, with some seeking alternatives on the international market, such as the purchase of breathing ventilators and PPE. The fact that they often did so without logistical assistance from the Ministry of Health meant that they encountered great difficulty in managing 
these imports, making the latter a further point of tension between the federal and state governments.

The commendable performance that states delivered at the start of the pandemic was, however, not always sustained. For example, economic and political pressures from the private sector, mainly from service associations wishing to reopen, led to various state governors relaxing restrictions sooner than recommended, with the result that the numbers of new cases and fatalities remained unchanged or even increased. Opinion polls suggest that governors hence saw a decline in their popularity ratings (Uol 2020a).

One crucial measure that states undertook was to set up field hospitals to increase the availability of ICUs. Prior to this, the number of ICU beds available differed substantially from state to state. It thus became necessary to provide beds urgently, especially in states with lower capacity. Ministry of Health data provided a clear picture of the inequality between states, showing that, on average, the SUS was meeting the WHO recommendations of one public bed per 1,000 inhabitants. However, 17 of the 26 states and the Federal District had not met this quota, while others (mostly in the Sand Southeast regions) greatly exceeded it (Albuquerque et al. 2017).

The urgent need to provide ICU beds gave rise to questionable administrative practices, with corruption scandals emerging in connection with the acquisition of materials and equipment as well as the contracting of service providers to establish and run Covid-19 field hospitals, in the process raising doubts about the probity of government officials. For instance, the governor of the state of Rio de Janeiro was temporarily removed from office by the courts due to suspicion of involvement in pandemic-related fraud (Superior Court of Justice, 2020).

What also became apparent was that inequalities in facilities translated into huge disparities between states in case numbers and fatalities. São Paulo, Bahia, Rio de Janeiro, and Ceará saw the largest numbers of cases and, by the same token, placed greater restrictions on people's movement than elsewhere; nevertheless, the federal government did nothing to address the situation, leaving states to their own devices and consequently aggravating the inequalities between the richest and the poorest. As an illustration, a judge from the state of Maranhão in the Northeast region ordered a full lockdown in its capital, São Luis, and three cities of the metropolitan region due to the lack of beds and high level of infections and deaths - the decision led to a 10-day lockdown and arose from a lawsuit filed by the office of the state public attorney (Carta Capital 2020). The governor, Flavio Dino, of Brazil's Communist Party and strongly opposed to Bolsonaro, received insufficient support from the union to combat Covid-19.

\subsubsection{Local government action}

Municipalities are recognised in the Constitution as federative entities with the autonomy to legislate and manage action on the basis of their local interests (Ribeiro and Pinto 2009). State capitals and large cities are the main actors in 
the local government scene. During the 2020 pandemic, many city councils stayed in operation by virtual means. For example, the city councils of Rio de Janeiro and São Paulo passed laws concerning the pandemic during virtual sessions. Some mayors, especially those of state capitals and large cities, introduced stricter measures than those adopted by state governments. These included making it mandatory to wear face masks and suspending or curtailing the provision of goods and services.

Municipalities too were subject to economic pressure from the sectors of the population that wished to reopen activities and see the adoption of more flexible modes of social isolation. Reopening has thus not always been in response to a reduced number of cases. State capitals such as Porto Alegre and São Paulo, which adopted responsible measures at the beginning of the pandemic, gave in to pressure and reopened, causing a drastic increase in the numbers of new cases and deaths. The pressure was not only economic but also political, given that, by virtue of a decision of the Superior Electoral Court, municipal elections took place throughout the country in November 2020; moreover, local politicians were reluctant to impose drastic social isolation measures for fear of paying the political cost in lost votes.

Another issue that merits attention is the capacity of local authorities to deal with the pandemic, including their technical capacity to provide adequate health care for patients with Covid-19. As noted, there were enormous disparities in the number of beds available from state to state and even within the same state. Many municipalities did not have ICUs and had to send patients to larger nearby municipalities; given that some states had very low capacity, citizens in towns often had to travel long distances to receive adequate care, losing precious treatment time as a result. In the state of Amazonas, for example, some localities were 12 hours' drive away from the nearest ICU, which they could sometimes access only by riverboat.

The pandemic has revealed Brazil's shortage of primary health-care resources and the failure on the part of the authorities to provide support for frontline health workers. Lotta et al. (2020) found that community health workers (CHWs) had not received enough training and safety equipment to be able to attend to patients or identify cases requiring hospitalisation. In July 2020, only 9 per cent of $\mathrm{CHW}$ seported having received proper instruction in how to deal with patients (Lotta et al. 2020). In some cities, CHWs with chronic health issues were asked to confine themselves to administrative duties and work remotely, while in others, such workers were obliged to continue providing direct care. This fact highlights that the wide-ranging autonomy the Constitution grants municipalities can lead to inequalities in the provision of public services to citizens.

Another situation that illustrates the extensiveness of local autonomy and the problems arising from it is the absence of regional coordination in metropolitan areas. A bizarre but representative case was that of a shopping mall in the state of São Paulo that straddles the boundary between the municipalities of Sorocaba 
and Votorantim. As no more ICU beds were available in the public sector in Sorocaba, the municipal authorities decided to reintroduce the policy of suspending commercial activities. Votorantim, however, kept the mall open for four hours a day, as mandated by the state government for municipalities in Phase 2 of the state's lockdown plan. As a result, the section of the mall located in the municipality of Votorantim reopened stores, while, in the section falling under the municipality of Sorocaba, stores remained closed. The mall thus remained partially open, and partially closed, as a result of a lack of regional coordination (Uol 2020b).

Although this is an extreme example, it shows the negative effects of the extensive local autonomy that is permitted in Brazil's federal system notwithstanding the absence of institutional mechanisms for horizontal intergovernmental coordination in cases of disaster management. This affects not only the opening of stores but also strategies to counter the pandemic itself, as the virus makes no distinction between the commerce of one municipality and that of a neighbouring one within an urban conurbation.

It was only in a few locations, such as the $\mathrm{ABC}$ region in the metropolitan area of São Paulo (with 20 million inhabitants), that municipalities engaged in horizontal intergovernmental cooperation with a view to addressing the pandemic in a coordinated way (Rodrigues and Oliveira 2020). This was especially important due to the large flow of people between these cities, mainly for work reasons.

\subsubsection{Intergovernmental relations}

Although its elements are envisaged as functioning cooperatively, the federal system in Brazil has not - except for single issues such as fiscal policy - developed or constitutionalised structures and mechanisms to enable vertical intergovernmental relations between the union and the states, despite the country's long history of shortcomings in the area of policy coordination (Arretche 2015; Souza 1997).

Intergovernmental coordination in Brazil varies not only in function of the institutional framework (polity), but also in regard to the specific design of the public policies. As such, because it stems from policies rather than being systemically embedded, the problem is that it is an unstable practice, one easily modified by changes in ordinary laws by the government of the day. A dramatic case in point is that the Bolsonaro government has been dismantling important structures for coordinating public policies, both in health and other socioeconomic such as social assistance. This was the case, for instance, with federal programmes, such as the Bolsa Familia, that could be used to render emergency assistance for the low-income population. It was discarded by the federal government in preference for providing federal resources to citizens through the Caixa Econômica Federal, a bank run by the federal government. With more than 60 million beneficiaries entitled to emergency benefits in Brazil, the bank was finding it difficult to distribute these benefits due to its capacity constraints (Stuchi et al. 2020). 
In a crisis such as the Covid-19 pandemic, people tend to look for guidance to the President because of his or her ability to bring the nation together around a consensus or majority position regarding the implementation of policy, a power which in most cases is accompanied by the transfer of federal resources to states for emergency action. This did not happen during the Covid-19 crisis.

To turn from vertical to horizontal intergovernmental relations, some states cooperated horizontally with each other during the 2020 pandemic. The states of the Northeast mobilised a regional consortium, one created in March 2019, and established the Scientific Committee to Control Coronavirus to advise governors on the political and administrative decision-making process regarding prevention and control of the pandemic (IREE 2020). As mentioned, instances of horizontal intergovernmental relations between municipalities were few and far between, even in situations where - as in the case of the bi-municipal shopping mall in São Paulo - their absence resulted in measures glaringly at cross-purposes with each other.

\subsubsection{Intergovernmental fiscal relations}

The pandemic had a major impact on the economic welfare of Brazil. Its gross domestic product (GDP) declined by 7.05 per cent from March to June 2020 (compared to June 2019), making this arguably the worst recession the country has witnessed in the past 120 years. The impact was especially detrimental for the states since their main revenue derives from their collection of value-added tax, or imposto sobre valor acrescentado (IVA), the amount of which was seriously affected by social isolation measures.

Although they have fiscal autonomy, states also receive federal transfers. In view of the pandemic, they were consequently more dependent on these transfers, as well as on public and private debts. By constitutional provision (article 158, IV Federal Constitution), local governments must receive 25 per cent of the IVA revenue collected by the states, in proportion to the economic activity in each one. Therefore, local government finances were also in peril, also because, especially in urban municipalities, the service tax (ISS) is one of the main sources of revenue, strongly impacted by the suppression or reduction of activities.

Public spending is also regulated by the Fiscal Responsibility Act of 2000, which establishes several limits and permanent procedures to avoid financial imbalance. Some of its main provisions are the limitation of spending on public employees and the prohibition on borrowing in the last year of the term. The declaration of a state of disaster via the Legislative Decree of 6 March 2020 enabled governments to dispense with some of the fiscal obligations imposed by the law. However, Constitutional Amendment 95 of 2016 established a 'ceiling' on federal government spending for 20 years, starting in 2017, to contain the growth in public debt. This ceiling was neither suspended nor relaxed during the pandemic. 
Furthermore, Complementary Law 173 of 27 May 2020 established the Federal Covid-19 Control Programme, with measures such as suspension of payment of state debts to the union, restructuring of financial credit operations, and the transfer of financial assistance from the union to the states. It also stipulated that the federal government has to provide financial aid to the states, the federal districts, and the municipalities to the sum of BRL 60 billion. The funds were to be distributed according to a number of criteria, including on the basis of demographic data and the incidence rate of Covid-19.

One of the great debates in Congress and among the financial sector was about the extent to which Brazil would be able to respect its debt ceiling or, failing that, the extent to which it was at risk of having to increase its domestic and international debt to unsustainable levels.

\subsection{Findings and policy implications}

Eight months after the first Covid-19 case in Brazil, the federal government was still berating subnational governments with the claim that governors and mayors were responsible for more than 160,000 deaths nationwide. Although the federal system has traditionally been centralised, management of the pandemic revealed the potential for decentralisation and for strengthening the scope of action of states and municipalities, which received support from the Supreme Court in their appeal for legitimisation of their measures to combat the virus.

Brazil saw a shift in the play of federative forces, with states and municipalities taking the lead in fighting the pandemic; conversely, the federal government, which usually has a coordinating role, saw two ministers of health leave the post amid a pandemic and wound up playing a secondary role in which it followed the actions of subnational entities - that is, when it was not intent on sabotaging them without proposing viable alternatives.

It may be argued therefore that the intergovernmental relations generated by the very nature of federalism were indispensable in enabling Brazil to address the pandemic and so prevent worse outcomes in terms of public health. Relations between states and municipal governments were fundamental in the struggle to contain the 2020 pandemic - although on occasion the country functioned as a unitary entity with a single central command structure directing public health measures, the present government alone would certainly not have been capable of providing effective responses to protect the health of the population, given that the President's denialist policy led him to act in opposition to WHO recommendations.

It is thus fair to say that federalism in Brazil fulfilled its core purpose of decentralising power and thereby protecting fundamental rights by instituting checks and balances on a wayward president. Ultimately, the role of the states was strengthened by the pandemic and their governments conducted themselves in a manner that warrants public trust. Local governments at city level nevertheless 
showed wide variation in their responses, which suggests that coordination with states was insufficient and should be improved.

Yet it is uncertain if the expanded autonomy of states and municipalities during the pandemic, due the Supreme Court decision, will lead to a more decentralised federation in the middle and long terms. Nevertheless, this precedent may produce an impact on the perception that decentralisation is not only good, but sometimes necessary, to protect lives against a centralist, non-rational rule.

\section{References}

Agência Brasil. 2020. https://agenciabrasil.ebc.com.br/saude/noticia/2020-03/veja-medidasque-cada-estado-esta-adotando-para-combater-covid-19 (accessed on 31 October 2020).

Albuquerque, Mariana Vercesi de, et al. 2017. 'Regional Health Inequalities: Changes Observed in Brazil from 2000-2016', Ciência \& Saúde Coletiva, 22(4): 1055-1064.

Araújo, Marcelo Labanca Corrêa de. 2009. Jurisdição Constitucional e Federação: o princípio da simetria na jurisprudência do STF. Rio de Janeiro: Elsevier.

Araújo, Marcelo Labanca Corrêa de and Leonam Liziero. 2020. 'Reposicionando o debate federalista no Brasil em razão da pandemia COVID-19: há mesmo uma tendência à descentralização?’, in João Paulo A. Teixeira (ed.), Pensar a Pandemia, pp. 380-391. Curitiba:Tirant Lo Blanch Brasil.

Arretche, Marta. 2015. 'Intergovernmental Relations in Brazil: An Unequal Federation with Symmetrical Arrangements', in J. Poirier, C. Saunders and J. Kincaid J (eds), Intergovernmental Relations in Federal Systems: Comparative Structures and Dynamics, pp. 108134. Oxford: Oxford University Press.

Candido, D. S. et al. 2020. 'Evolution and the Pandemic Spread of Sars-CoV-2 in Brazil', Science, https://science.sciencemag.org/content/369/6508/1255 (accessed on 1 November 2020).

Carta Capital. 2020. https://www.cartacapital.com.br/sociedade/justica-ordena-lockdownem-sao-luis-no-maranhao/ (accessed on 1 November 2020).

Castro, Marcus F. and Gilberto M. A. Rodrigues. 2010. 'Brazil', in C. Colino and L. Moreno (eds), Diversity and Unity in Federal Countries, pp. 76-108. Montreal: McGill-Queens University Press.

CNN Brasil. 2020. https://www.cnnbrasil.com.br/nacional/2020/11/16/sem-demandanos-estados-400-mil-comprimidos-de-cloroquina-encalham-no-exercito (accessed on 15 November 2020).

Connectas Human Rights. 2020. 'Why Bolsonaro could be Denounced at the International Criminal Court', https://www.conectas.org/en/news/why-bolsonaro-could-bedenounced-at-the-international-criminal-court (accessed on 15 November 2020).

Department of Health. 2020. 'Coronavirus (Covid-19)', https://coronavirus.saude.gov.br/ linha-do-tempo (accessed on 31 October 2020).

Ferrari, Sergio. 2015. 'Local Government in Brazil and Switzerland: A Comparative Study on Merger an Inter-Municipal Cooperation', pp. 36-43, Institute of Federalism, University of Fribourg, https://www3.unifr.ch/federalism/en/assets/public/files/ Workingpercent20Paperpercent20online/06_Sergiopercent20Ferrari.pdf (accessed on 31 October 2020).

Fiocruz. 2020. https://portal.fiocruz.br/pesquisas-notas-tecnicas-e-relatorios (accessed on 28 November 2020). 
França, Elisabeth Barboza et al. 2020. 'Deaths Due to COVID-19 in Brazil: How Many Are There and Which Are Being Identified?', Revista Brasileira de Epidemiologia, Rio de Janeiro, 23, e200053.

IBGE (Instituto Brasileiro de Geografia e Estatística). 2019a.'Pirâmide Etária', https://educa. ibge.gov.br/jovens/conheca-o-brasil/populacao/18318-piramide-etaria.html (accessed on 31 October 2020).

IBGE (Instituto Brasileiro de Geografia e Estatística).2019b. 'Data base on Indigenous Peoples and Quilombolas', https://www.ibge.gov.br/en/geosciences/territorial-organization/ territorial-typologies/27488-base-de-informacoes-sobre-os-povos-indigenas-equilombolas-2.html? =\&t=o-que-e (accessed on 31 October 2020).

Imperial College. 2020. https://mrc-ide.github.io/global-lmic-reports/BRA (accessed on 31 October 2020).

Instituto para Reforma das Relações entre Estado e Empresa (IREE). 2020. https://iree.org. br/consorcio-nordeste-entenda-o-que-e-a-iniciativa/ (accessed on 30 October 2020).

Lorencini, Marco A. G. L, Gilberto M. A. Rodrigues, and A. Zimmermann. 2017. 'The Supreme Federal Court of Brazil: Protecting Democracy and Centralized Power', in N. Aroney and J. Kincaid (eds), Courts in Federal Countries: Federalists or Unitarists, pp. 103-134. Toronto: University of Toronto Press.

Lotta, G. et al. 2020. 'Community Health Workers Reveal COVID-19 Disaster in Brazil', The Lancet, 396: 365-66.

Magno, L. et al. 2020.'Challenges and Proposals for Scaling up COVID-19 Test and Diagnosis in Brazil', Ciência \& Saúde Coletiva, 25(9): 3355-64.

Notícias STF, 2020. http://www.stf.jus.br/portal/cms/verNoticiaDetalhe.asp?idConteudo= 448639 (accessed on 21 January 2021).

OECD. 2019. 'Health at a Glance 2019: OECD Indicators', OECD Publishing, https:// www.oecd-ilibrary.org/social-issues-migration-health/health-at-a-glance-2019_ 4dd50c09-en (accessed on 31 October 2020).

Our World in Data. 2020. 'Table (line 9488, column AB)'. https://ourworldindata.org/ coronavirus-testing (accessed on 31 October 2020).

Ribeiro, L. C. de Queiroz Ribeiro and Sol Garson B. Pinto. 2009. 'Brazil', in N. Steytler (ed.), Local Government and Metropolitan Regions in Federal Systems, pp. 75-105. Montreal: McGill-Queen's University Press.

Rodrigues, Gilberto M.A. 2017. 'Concurrent Power and Local Interest in Brazil's Federalism', in N. Steytler (ed.), Concurrent Powers in Federal Systems: Meaning, Making, and Managing, pp. 206-221. Leiden, Boston: Brill Nijhoff.

Rodrigues, Gilberto M. A. 2018. 'Are Cities Constituent Units in Brazil's Federalism?', 50 Shades of Federalism, http://50shadesoffederalism.com/case-studies/cities-constituentunits-brazils-federalism/ (accessed on 31 October 2020).

Rodrigues, Gilberto. M.A. and Vanessa E. Oliveira. 2020. 'Brazil and Covid-19: the President against the Federation', UACES Territorial Politics, https://uacesterrpol.wordpress. com/2020/06/05/brazil-and-covid-19-the-president-against-the-federation/ (accessed on 31 October 2020).

Scheffer, Mário, et al. 2015. Brazilian Medical Demographics (Demografia médica no Brasil). São Paulo: Departamento de Medicina Preventiva da Faculdade de Medicina da USP; Conselho Regional de Medicina do Estado de São Paulo; Conselho Federal de Medicina.

Souza, Celina. 1997. Constitutional Engineering in Brazil: The Politics of Federalism and Decentralization. London: Palgrave Macmillan.

Stuchi, Carolina G., Vanessa E. Oliveira and Gilberto M. A Rodrigues. 2020. 'Covid-19 and Emergency Grant: Brazil's Populist Policy?’, UACES Territorial Politics, https:// 
uacesterrpol.wordpress.com/2020/09/24/covid-19-and-emergency-grant-a-brazilspopulist-policy/ (accessed on 31 October 2020).

Superior Court ofJustice.2020.https://www.stj.jus.br/sites/portalp/Paginas/Comunicacao/ Noticias/28082020-STJ-afasta-o-governador-Witzel-do-cargo-e-prende-seisinvestigados-por-irregularidades-na-Saude-do-Rio.aspx (accessed on 30 October 2020).

Tribunal de Contas da União (TCU). 2020. https://portal.tcu.gov.br/english/inside-tcu/ the-court/ (accessed on 4 September 2020).

Uol. 2020a. http://media.folha.uol.com.br/datafolha/2020/06/26/66ed4921092c48022554df 364b7a3464gvnts.pdf (accessed on 4 September 2020).

Uol. 2020b. https://noticias.uol.com.br/cotidiano/ultimas-noticias/2020/06/24/votorantimpromotor-diz-que-shopping-dividido-e-absurdo-e-pede-explicacoes.htm (accessed on 28 August 2020). 